\title{
HUBUNGAN TINGKAT PARTISIPASI IBU MENGIKUTI POSYANDU DENGAN STATUS GIZI BALITA DI DESA MULUR RT 03/VI BENDOSARI SUKOHARJO
}

\author{
Ratna Indriati ${ }^{1}$, Christin Lidyawati ${ }^{2}$
}

\begin{abstract}
Posyandu is a method to monitor growth child. The scope of children is an indicator of public participation in posyandu.The percentage of the scope of children weighed in Central Java in 2015 is $73.9 \%$, decrease compared to the 2014 80.4\%. Posyandu activities in the village Mulur is routinely performed every month, but some women not routinely come, and still found children with a weight less. Purpose and benefit : to know relations participation mother follow posyandu with the status of nutrition child. Benefits research is provide an illustration of the importance of follow posyandu activities as an effort to increase the nutrition of child.

The subject of study: 35 mother and child age $1-5$ years in posyandu village Mulur Sukoharjo. Method: research of analytic observation, design correlation with the cross sectional. The sample of this study in total sampling. The data analysis by test chi square with $\mathrm{p}=0.05$.

The result of research show mother to the level of active participation 13 people (37.14\%), less active 10 people (28.57\%) not active 12 people (34.29\%).Children with nutrition good 23 children $(65.71 \%)$ and malnutrition 12 children (34.29\%). The results of the analysis use test chi square obtained $p=0.039(p<0.05)$ which means Ha received. Conclusion: there was a correlation level of participation mother follow posyandu with the status nutrition of child.
\end{abstract}

Keywords: Level of participation, posyandu activities, nutritional status of child

\section{PENDAHULUAN}

Kesehatan gizi masyarakat merupakan salah satu unsur penting dalam kemajuan suatu bangsa, sehingga perlu mendapatkan perhatian yang serius terutama status gizi pada anak usia di bawah lima tahun (balita), oleh karena pada usia ini anak berada pada periode tumbuh kembang yang sangat pesat. Kekurangan gizi yang terjadi pada masa balita akan menghambat pertumbuhan dan perkembangan yang optimal dimana akan mempengaruhi kualitas kehidupan pada usia dewasa. Status gizi adalah status kesehatan yang dihasilkan antara kebutuhan dan masukan nutrien (Adnani, 2011).

Berdasarkan laporan kesehatan dasar (Riskesdas), prevalensi balita di Indonesia yang mengalami kekurangan gizi pada tahun 2010 adalah $17.9 \%$ dan mengalami peningkatan sebesar $19.6 \%$ pada tahun 2013, sedangkan target yang ingin dicapai pada tahun 2019 adalah 17\% (Kemenkes, 2013). Data dari profil kesehatan Provinsi Jawa Tengah tahun 2013, persentase balita dengan gizi kurang (BB/U) Provinsi Jawa Tengah tahun 2013 sebesar $3.86 \%$ dan balita gizi buruk berjumlah $2.475(0.30 \%)$, jumlah balita gizi buruk di Jawa Tengah mengalami penurunan yaitu sebesar 922 kasus pada tahun 2015 (Profil Kesehatan Provinsi Jawa Tengah, 2015).

Penyebab masalah gizi adalah penyebab langsung yaitu makanan anak dan penyakit infeksi sedangkan penyebab tidak langsung yaitu ketahanan pangan di keluarga, pola pengasuhan anak, serta pelayanan kesehatan dan 
kesehatan lingkungan, tingkat ekonomi, pendidikan dan sosial budaya (Adnani, 2011).

Kebutuhan gizi balita adalah jumlah yang diperkirakan cukup untuk memelihara kesehatan pada umumnya. Secara garis besar, kebutuhan gizi ditentukan oleh usia, jenis kelamin, aktivitas, berat badan dan tinggi badan. Antara asupan zat gizi dan pengeluaran harus ada keseimbangan sehingga diperoleh status gizi yang baik. Status gizi balita dapat dipantau dengan menimbang anak setiap bulan di Posyandu dan dicocokkan dengan Kartu Menuju Sehat (Marimbi, 2010). Menurut Irianto (2014), status gizi diklasifikasikan berdasarkan berat badan menurut usia (BB/U), tinggi badan menurut usia (TB/U), dan berat badan menurut tinggi badan (BB/TB).

Posyandu merupakan pelayanan kesehatan masyarakat dan oleh masyarakat yang mempunyai nilai strategis dalam mengembangkan sumber daya manusia sejak dini. Posyandu balita sebagai pusat kegiatan masyarakat dalam upaya pelayanan kesehatan untuk balita. Posyandu merupakan lembaga yang paling baik dan paling dekat dengan masyarakat, sehingga ideal untuk diterapkan di negara Indonesia (Mubarak dan Chayatin, 2009).

Jumlah balita ditimbang di Posyandu merupakan data indikator terpantaunya pertumbuhan balita melalui pengukuran perubahan berat badan setiap bulan sesuai umur. Balita yang rutin menimbang adalah balita yang selalu terpantau pertumbuhannya. Kehadiran balita di Posyandu merupakan hasil dari akumulasi peran serta ibu, keluarga, kader, dan seluruh komponen masyarakat dalam mendorong, mengajak, memfasilitasi, dan mendukung balita agar ditimbang di Posyandu untuk dipantau pertumbuhannya. Dengan demikian cakupan balita ditimbang

merupakan indikator partisipasi masyarakat dalam kegiatan Posyandu. Persentase cakupan balita ditimbang di Jawa Tengah pada tahun 2015 sebesar 73.9\%, mengalami penurunan bila dibandingkan dengan persentase tahun 2014 yaitu $80.4 \%$. Target partisipasi masyarakat dalam kegiatan Posyandu di Jawa Tengah adalah $80 \%$, hal ini menunjukkan tingkat partisipasi masyarakat pada tahun 2015 masih di bawah target (Kemenkes, 2015).

Partisipasi masyarakat adalah keikutsertaan anggota masyarakat dalam memecahkan permasalahanpermasalahan masyarakat tersebut (Notoadmodjo, 2012). Dengan demikian partisipasi ibu dalam kegiatan Posyandu balita adalah keikutsertaan ibu dalam mengikuti kegiatan di Posyandu yang membantu ibu untuk menyelesaikan permasalahan kesehatan pada anak. Ibu yang mengikuti kegiatan Posyandu akan lebih mengetahui status gizi anaknya karena dapat melihat dan selalu memantau di buku KMS, selain itu dengan mengikuti kegiatan di Posyandu ibu juga bisa memperoleh penyuluhan kesehatan termasuk penyuluhan mengenai gizi pada balita (Mubarak dan Chayatin, 2009).

Hasil penelitian yang dilakukan oleh Daud (2015), mengenai hubungan partisipasi ibu mengikuti kegiatan Posyandu dengan status gizi di Desa Tabumela Gorontalo menunjukkan balita yang memiliki status gizi baik dan tingkat partisipasi ibu aktif sebanyak $73.4 \%$, balita yang memiliki status gizi kurang dengan tingkat partisipasi ibu tidak aktif sebanyak $26.6 \%$ dan status gizi buruk dengan tingkat partisipasi ibu tidak aktif sebanyak $26.6 \%$. Hasil penelitian tersebut menunjukkan terdapat hubungan bermakna antara tingkat partisipasi 
ibu mengikuti kegiatan Posyandu dengan status gizi anak ( $p=0.000)$. Hasil survey awal yang dilakukan di Desa Mulur Sukoharjo, dari wawancara pada kader Posyandu diperoleh informasi bahwa jadwal kegiatan Posyandu di Desa Mulur dilakukan setiap bulan sekali, tetapi ada beberapa ibu yang tidak rutin datang ke posyandu karena ada kesibukan lain bersamaan dengan kegiatan posyandu dan ada juga ibu yang mengatakan lupa dengan jadwal posyandu, meskipun jadwal posyandu sudah diumumkan sebelumnya. Dari hasil penimbangan balita masih dijumpai beberapa anak yang berat badannya tidak naik dan tidak sesuai dengan usianya. Selama ini belum pernah dilakukan penelitian mengenai partisipasi ibu dalam kegiatan posyandu dan hubungannya dengan status gizi balita di Desa Mulur.

Berdasarkan uraian di atas maka penulis tertarik melakukan penelitian tentang "Hubungan Tingkat Partisipasi lbu Mengikuti Kegiatan Posyandu dengan Status Gizi Balita di Desa Mulur RT 3/VI Bendosari Sukoharjo".

\section{TUJUAN PENELITIAN}

Penelitian ini secara umum bertujuan untuk mengetahui hubungan tingkat partisipasi ibu mengikuti kegiatan posyandu dengan status gizi balita, serta secara khusus untuk mengetahui gambaran tingkat partisipasi ibu mengikuti kegiatan posyandu dan gambaran status gizi balita di Desa Mulur RT 3/VI Bendosari Sukoharjo.

\section{METODE/DESAIN PENELITIAN}

Penelitian ini merupakan penelitian korelasi dengan pendekatan cross sectional untuk mengetahui hubungan antara tingkat partisipasi ibu dalam mengikuti kegiatan posyandu dengan status gizi balita di Desa Mulur Bendosari Sukoharjo.
POPULASI, SAMPEL DAN TEKNIK SAMPLING

Populasi penelitian adalah ibu beserta anak umur $1-5$ tahun di Posyandu Anggrek Desa Mulur yang berjumlah 35 responden. Sampel penelitian adalah semua ibu beserta anak umur $1-5$ tahun di Posyandu Anggrek Desa Mulur yang berjumlah 35 responden, sehingga dalam penelitian ini peneliti menggunakan teknik sampling jenuh dimana seluruh anggota populasi dipakai sebagai responden penelitian.

\section{HASIL PENELITIAN}

Berdasarkan penelitian yang telah dilakukan didapatkan karakteristik responden berdasarkan umur ibu, pendidikan ibu, pekerjaan ibu dan umur anak beserta hasil penelitian mengenai hubungan tingkat partisipasi ibu dalam mengikuti kegiatan posyandu dengan status gizi balita di Desa Mulur Bendosari Sukoharjo, yaitu sebagai berikut :

Tabel 1.

Distribusi Frekuensi

Karakteristik Responden

\begin{tabular}{cccc}
\hline Karakteristik & Kategori & $\mathrm{f}$ & $\%$ \\
\hline Umur Ibu & $21-30$ & 21 & 60.0 \\
(th) & $31-40$ & 13 & 37.1 \\
& $41-50$ & 1 & 2.9 \\
Pendidikan & SD & 1 & 2.8 \\
& SMP & 3 & 8.6 \\
& SMA & 28 & 80.0 \\
& S1 & 3 & 8.6 \\
Pekerjaan & Guru & 2 & 5.7 \\
& PNS & 1 & 2.9 \\
& Swasta & 2 & 5.7 \\
& Ibu RT & 30 & 85.7 \\
Umur Anak & $1-3$ & 30 & 85.7 \\
(th) & $>3-5$ & 5 & 14.3 \\
\hline
\end{tabular}

Berdasarkan tabel di atas menunjukkan umur ibu yang paling banyak adalah 21 - 30 tahun yaitu sebanyak 21 ibu (60\%), pendidikan terbanyak adalah SMA yaitu 28 ibu 
$(80 \%)$, sebagian besar ibu sebagai ibu rumah tangga yaitu 30 ibu (85.7\%), dan umur anak terbanyak adalah 1 - 3 tahun yaitu 30 anak (85.7\%).

Tabel 2.

Distribusi Frekuensi Tingkat Partisipasi lbu dalam Posyandu

\begin{tabular}{lcc}
\hline Tingkat & $\mathrm{f}$ & $\%$ \\
Partisipasi & 13 & 37.1 \\
\hline Aktif & 10 & 28.6 \\
Kurang aktif & 12 & 34.3 \\
Tidak aktif & 35 & 100 \\
\hline Total &
\end{tabular}

Data di atas dapat menunjukkan jumlah responden paling banyak adalah responden dengan tingkat partisipasi aktif yaitu sebanyak 13 ibu (37.1\%), responden yang tidak aktif mengikuti kegiatan posyandu sebanyak 12 ibu (34.3\%) dan jumlah paling sedikit adalah partisipasi kurang aktif yaitu 10 ibu (28.6\%).

Tabel 3.

Distribusi Frekuensi Status Gizi Balita

\begin{tabular}{lcc}
\multicolumn{3}{c}{ Status Gizi Balita } \\
\hline Status Gizi & $\mathrm{f}$ & $\%$ \\
\hline Baik & 23 & 65.7 \\
Kurang & 12 & 34.3 \\
\hline Total & 35 & 100 \\
\hline
\end{tabular}

Dari tabel di atas dapat diketahui bahwa jumlah responden yang memiliki anak dengan status gizi baik lebih banyak yaitu 23 orang $(65.7 \%)$ dibandingkan status gizi kurang yaitu sejumlah 12 orang (34.3\%).
Tabel 4.

Analisa Bivariat Hubungan Tingkat Partisipasi lbu dengan Status Gizi Anak

\begin{tabular}{lcccc}
\hline $\begin{array}{l}\text { Tingkat } \\
\text { Partisipa } \\
\text { si }\end{array}$ & \multicolumn{2}{c}{ Status Gizi } & & \\
\cline { 2 - 3 } & Baik & Kurang & & \\
\hline Aktif & 12 & 1 & 13 & 0.039 \\
& $(92.3)$ & $(7.7)$ & $(100)$ & 0.7 \\
Kurang & 5 & 5 & 10 & \\
aktif & $(50.0)$ & $(50.0)$ & $(100)$ & \\
Tidak & 6 & 6 & 12 & \\
aktif & $(50.0)$ & $(50.0)$ & $(100)$ & \\
& 23 & 12 & 35 & \\
Total & $(65.7)$ & $(34.3)$ & $(100)$ & \\
\hline
\end{tabular}

Hasil dari uji Chi-Square program SPSS versi 18.0 dengan $\alpha=5 \%$ (0.05) diperoleh $p$ sebesar 0.039 sehingga nilai $p<0.05$, yang berarti Ho ditolak dan $\mathrm{H}_{\mathrm{a}}$ diterima sehingga ada hubungan tingkat partisipasi lbu dalam kegiatan posyandu dengan status gizi anak usia $1-5$ tahun di Posyandu Anggrek 2 Desa Mulur Bendosari Kabupaten Sukoharjo.

\section{PEMBAHASAN}

1. Tingkat Partisipasi dalam Posyandu

Berdasarkan hasil penelitian menunjukkan tingkat partisipasi ibu balita mengikuti kegiatan posyandu yang terbanyak adalah partisipasi aktif yaitu sebanyak 13 ibu (37.1\%).

Kehadiran balita di Posyandu merupakan hasil dari akumulasi peran serta ibu, keluarga, kader, dan seluruh komponen masyarakat dalam mendorong, mengajak, memfasilitasi, dan mendukung balita agar ditimbang di Posyandu untuk dipantau pertumbuhannya. Dengan demikian cakupan balita ditimbang merupakan indikator partisipasi masyarakat dalam kegiatan Posyandu (Kemenkes, 2015). 
Berdasarkan observasi yang dilakukan di posyandu Anggrek sebagian besar ibu balita sudah aktif melakukan penimbangan balita di posyandu. Dari ibu yang aktif tersebut hampir seluruhnya adalah ibu rumah tangga dan hanya ada satu ibu yang bekerja. Dengan ibu yang tidak bekerja dimungkinkan lebih bisa meluangkan waktu untuk datang ke posyandu, namun hal ini juga bisa menunjukkan ibu balita tersebut sudah memiliki kesadaran mengenai pentingnya mengikuti kegiatan posyandu bagi anak balitanya sehingga secara rutin membawa anaknya ke posyandu.

Meskipun sebagian besar ibu sudah aktif dalam kegiatan posyandu, namun masih cukup banyak juga ibu yang tidak aktif mengikuti posyandu yaitu $12 \mathrm{ibu}$ (34.3\%). Dari wawancara yang dilakukan pada ibu yang tidak rutin datang ke posyandu, penyebab yang paling banyak ibu balita tidak mengikuti kegiatan posyandu adalah lupa dengan jadwal posyandu, karena kesibukan ibu dengan urusan pekerjaan rumah tangga dan juga karena ibu yang bekerja.

Untuk meningkatkan partisipasi ibu balita dalam kegiatan penimbangan di posyandu, peran kader posyandu sangat diperlukan yaitu untuk selalu mengingatkan ibu balita mengenai jadwal kegiatan penimbangan di posyandu dan meningkatkan pengetahuan ibu mengenai pentingnya melakukan penimbangan balita sehingga ibu balita bersedia untuk berpartisipasi dalam kegiatan posyandu dengan kesadaran sendiri bukan karena paksaan. $\mathrm{Hal}$ ini sesuai dengan yang disampaikan oleh Notoatmodjo (2012), bahwa partisipasi masyarakat didalam pelayanan kesehatan merupakan sesuatu yang tumbuh dan berkembang dari bawah dengan rangsangan dan bimbingan dari atas, bukan sesuatu yang dipaksa dari atas. Melalui partisipasi, setiap anggota masyarakat dirangsang untuk belajar berorganisasi dan mengambil peran yang sesuai dengan kemampuan mereka masing-masing.

Cara untuk menumbuhkan partisipasi masyarakat menurut Notoatmodjo (2012) adalah dengan persuasi dan edukasi, yakni partisipasi yang didasari pada kesadaran, sulit ditumbuhkan dan akan memakan waktu yang lama, tetapi bila tercapai hasilnya akan mempunyai rasa memiliki dan rasa memelihara. Partisipasi ini dimulai dengan penerangan, pendidikan dan sebagainya, baik secara langsung maupun tidak langsung.

2. Status Gizi Anak

Status gizi merupakan suatu keadaan fisik seseorang atau kelompok orang ditentukan dengan salah satu kombinasi dari ukuran gizi tertentu (Adnani, 2011). Status gizi balita diukur berdasarkan umur, berat badan (BB) dan tinggi badan (TB). Salah satu penilaian status gizi berdasarkan indikator antropometri berat badan menurut umur (BB/U), dimana untuk menilai status gizi anak, diukur dengan menggunakan tabel berat badan menurut umur sesuai standar Harvard. Selanjutnya berdasarkan standar Harvard ditentukan kategori status gizi anak yaitu kategori gizi baik jika BB/U lebih dari $80 \%$ standar Harvard, gizi kurang jika BB/U $60.1 \%$ - $80 \%$ standar Harvard dan gizi buruk jika BB/U $\leq 60 \%$ standar Harvard (Irianto, 2014). Berdasarkan tabel 3 menunjukkan anak dengan status 
gizi baik sebanyak 23 anak $(65.7 \%)$ dan status gizi kurang sebanyak 12 anak (34.3\%). Dari data tersebut dapat diketahui bahwa sebagian besar anak memiliki status gizi baik.

Menurut Adnani (2011), penyebab langsung dari kurang gizi atau yang bisa mempengaruhi status gizi pada anak adalah asupan makanan dan penyakit infeksi, serta penyebab tidak langsung diantaranya pola pengasuhan anak yang dilakukan oleh orang tua. Penyakit infeksi yang menyerang anak akan mempengaruhi status gizi anak karena dengan penyakit infeksi dapat menyebabkan turunnya nafsu makan sehingga masukan zat gizi berkurang. Dan disisi lain kebutuhan tubuh akan makanan meningkat akibat dari adanya infeksi, sehingga bila anak menderita penyakit infeksi yang berkepanjangan maka akan berdampak pada status gizi anak menjadi kurang bahkan anak bisa memiliki status gizi buruk. Dalam penelitian ini tidak ada anak yang memiliki riwayat penyakit infeksi yang bersifat kronis, hal ini memungkinkan anak memiliki status gizi yang baik. Dari observasi sebagian besar anak dengan status gizi baik dan tidak ditemukan anak dengan status gizi buruk

Faktor lain yang mempengaruhi status gizi anak adalah pola asuh orang tua dalam hal ini ibu dalam pemenuhan asupan makanan bagi anak. Karakteristik ibu yang berhubungan dengan pola asuh makan diantaranya adalah tingkat pendidikan ibu dan status pekerjaan ibu. Seperti hasil penelitian Wardani (2012), menunjukkan bahwa faktor yang mempengaruhi status gizi balita diantaranya adalah tingkat pendidikan ibu yang tinggi
(50.5\%) dan ibu tidak bekerja (83.9\%). Tingkat pendidikan dalam keluarga khususnya ibu dapat menjadi faktor yang mempengaruhi status gizi anak. Semakin tinggi pendidikan ibu maka pengetahuannya tentang gizi akan lebih baik dari yang berpendidikan rendah, karena ibu akan memiliki kemampuan yang semakin tinggi untuk menyerap informasi - informasi yang diperoleh baik dari media massa maupun dari pendidikan formal (Mubarak dan Chayatin, 2009). Dalam penelitian ini sebagian besar ibu berpendidikan SMA (80\%) bahkan ada 3 ibu (8.6\%) dengan pendidikan Sarjana. Dengan latar belakang pendidikan responden yang sebagian besar berpendidikan minimal SMA maka memungkinkan untuk memiliki pengetahuan yang baik tentang gizi pada anak, hal ini bisa menjadi faktor pendukung sehingga sebagian besar anak di posyandu Anggrek memiliki status gizi yang baik.

Selain pendidikan, status pekerjaan ibu juga bisa mempengaruhi status gizi anak. Menurut Berg dalam Wardani (2012), Ibu yang bekerja dari pagi hingga sore kurang memiliki waktu yang cukup bagi anak anak dan keluarga, karena ibu memiliki peran ganda yaitu sebagai ibu rumah tangga dan wanita pekerja, sehingga ibu perlu memiliki strategi dalam mengatur waktu supaya peran ganda yang dijalankan bisa seimbang termasuk dalam memperhatikan makanan anak yang sesuai dengan kebutuhan serta kecukupannya. Dalam penelitian ini sebagian besar ibu adalah ibu rumah tangga (85.7\%), sehingga memungkinkan ibu memiliki lebih banyak waktu di rumah untuk 
merawat anak termasuk dalam memberikan makan yang sesuai bagi anak dan ibu juga memiliki waktu untuk membawa anaknya ke posyandu. Dengan mengikuti posyandu maka pertumbuhan atau status gizi anak dapat terpantau setiap bulan. Kondisi tersebut bisa menjadi salah satu faktor yang mempengaruhi status gizi anak sehingga sebagian besar balita di posyandu Anggrek desa Mulur memiliki status gizi yang baik.

3. HubunganTingkat Partisipasi lbu dalam Kegiatan Posyandu dengan Status Gizi Balita

Hasil uji Chi-Square program SPSS versi 18.0 dengan $\alpha=5 \%$ (0.05) diperoleh $p$-value sebesar 0.039. Dari hasil tersebut menunjukkan nilai $p<0.05$ yang berarti $\mathrm{Ho}$ ditolak dan $\mathrm{H}_{\mathrm{a}}$ diterima sehingga ada hubungan antara tingkat partisipasi ibu dalam kegiatan posyandu dengan status gizi balita di posyandu Anggrek 2 Desa Mulur Bendosari Sukoharjo. Semakin aktif ibu mengikuti kegiatan posyandu, status gizi balita akan baik juga. Hal ini bisa dilihat pada lbu yang tingkat partisipasinya aktif, anak dengan status gizi baik 12 (92.3\%) lebih tinggi dibanding yang status gizinya kurang yaitu 1 anak (7.7\%). Sebaliknya ibu yang tingkat partisipasinya kurang aktif dan tidak aktif, jumlah anak dengan status gizi baik sama dengan status gizi kurang (50\%).

Cakupan penimbangan balita di posyandu merupakan salah satu upaya peningkatan gizi balita. Balita yang dilakukan penimbangan secara rutin di posyandu maka pertumbuhannya akan terpantau secara intensif. Apabila terdapat gangguan pertumbuhan maka dapat segera dilakukan upaya pemulihan atau pencegahan sehingga tidak menjadi gizi kurang atau gizi buruk. Semakin cepat ditemukan maka penanganan kasus gizi kurang atau gizi buruk akan semakin baik (Kemenkes, 2015). Kegiatan lain yang dilakukan di posyandu adalah pemberian makanan tambahan bagi yang berat badannya kurang, penyuluhan, pemberian oralit untuk menanggulangi diare, dan pengobatan penyakit sebagai pertolongan pertama (Mubarak dan Chayatin, 2009). Dengan kegiatan tersebut maka akan membantu balita tetap dalam keadaan sehat sehingga asupan nutrisi meningkat dan balita akan memiliki status gizi yang baik.

Demikian juga analisa pada hasil penelitian ini dimana ibu yang rutin mengikuti kegiatan posyandu memungkinkan pertumbuhan dan kesehatan anaknya terpantau sehingga jika ada gangguan maka cepat diketahui dan ditindaklanjuti. Dengan mengikuti kegiatan posyandu ibu juga bisa memperoleh informasi mengenai kesehatan anak khususnya dalam memenuhi nutrisi yang dibutuhkan bagi anak. Kemampuan untuk menyerap informasi tersebut juga didukung oleh tingkat pendidikan ibu yang sebagian besar SMA bahkan ada ibu dengan tingkat pendidikan sarjana.

Hasil penelitian ini yang menunjukkan adanya hubungan antara tingkat partisipasi ibu dalam kegiatan posyandu dengan status gizi balita juga telah dibuktikan oleh penelitian yang dilakukan oleh Sugiyarti, Aprilia dan Hati (2014), yang berjudul hubungan kepatuhan kunjungan posyandu dan status gizi balita. Hasil penelitian menunjukkan semakin tinggi kepatuhan kunjungan balita ke posyandu mempengaruhi status gizi balita. Demikian juga 
penelitian yang dilakukan oleh Lanoh, Sarimin, dan Karundeng (2015), menunjukkan ada hubungan positif antara pemanfaatan posyandu dengan status gizi balita yaitu balita yang memanfaatkan posyandu memiliki status gizi baik yang lebih tinggi dibanding balita yang tidak memanfaatkan posyandu.

Demikian juga pada penelitian ini tingkat partisipasi ibu dalam kegiatan posyandu mempengaruhi status gizi balita, dimana semakin baik partisipasi ibu dalam kegiatan posyandu maka semakin baik pula status gizi anak.

\section{KESIMPULAN}

1. Sebagian besar lbu (37.1\%) aktif dalam mengikuti kegiatan posyandu.

2. Status gizi balita lebih banyak pada status gizi baik yaitu 23 anak $(65.7 \%)$ dibandingkan status gizi kurang yaitu 12 anak (34.3\%).

3. Hasil uji Chi-Square diperoleh $p$ sebesar 0.039 yang berarti $\mathrm{H}_{\mathrm{a}}$ diterima, hal ini menunjukkan ada hubungan antara tingkat partisipasi lbu dalam mengikuti kegiatan posyandu dengan status gizi balita di posyandu Anggrek desa Mulur Bendosari Sukoharjo.

\section{SARAN}

1. Bagi orang tua yang memiliki anak balita agar meningkatkan partisipasinya dalam kegiatan posyandu untuk meningkatkan status gizi balita.

2. Bagi Puskesmas Kecamatan Bendosari diharapkan hasil penelitian ini dijadikan media untuk menambah pengetahuan tentang bagaimana cara yang baik untuk meningkatkan status gizi balita.

3. Bagi Kader posyandu hendaknya tetap memotivasi ibu balita untuk aktif berpartisipasi dalam kegiatan posyandu dalam upaya untuk meningkatkan status gizi balita

\section{DAFTAR PUSTAKA}

Adnani, H. 2011. Ilmu Kesehatan Masyarakat. Nuha Medika, Yogyakarta.

Daud, N. 2015. Hubungan Tingkat Partisipasi lbu Mengikuti Kegiatan Posyandu Dengan Status Gizi Balita di Desa Tabumela Kecamatan Tilango Kabupaten Gorontalo. Skripsi. Universitas Negeri Gorontalo, Gorontalo.

Irianto, K. 2014. IImu Kesehatan Anak Pediatri. Alfabeta, Bandung.

Kemenkes. 2013. Data Status Gizi Badan Penelitian dan

Pengembangan Kesehatan Departemen Kesehatan Republik Indonesia 2013. Laporan Riset Kesehatan Dasar (RISKESDAS) Departemen Kesehatan Republik Indonesia. Kemenkes, Jakarta. - 2013. Profil Kesehatan Provinsi Jawa Tengah tahun 2013.

URL:

www.dinkesjatengprov.go.id/ profil_2013. Di unduh tanggal 10 Desember 2016.

Lanoh, M., S. Sarimin, dan M. Karundeng. 2015. "Hubungan Pemanfaatan Posyandu dengan Status Gizi Balita Di Werukota Manado". e-jaurnal Keperawatan Volume 3. Diunduh pada tanggal 9 Desember 2016.

Marimbi, H. 2010. Tumbuh Kembang Status Gizi dan Imunisasi Dasar pada Balita. Nuha Medika, Yogyakarta.

Mubarak, W.I. dan N. Chayatin. 2009. IImu Kesehatan Masyarakat Teori dan Aplikasi. Salemba Medika, Jakarta. 
Notoadmodjo, S. 2012. Promosi Kesehatan dan IImu Perilaku. Rineka Cipta, Jakarta.

Profil Kesehatan Provinsi Jawa Tengah tahun 2015. www.dinkesjatengprov.go.id/ profil_2015. Di unduh tanggal 10 Desember 2016.

Sugiyarti, R., V. Aprilia dan F.S. Hati. 2014. "Kepatuhan Kunjungan Posyandu dan Status Gizi Balita di Posyandu Karang Bendo Banguntapan, Bantul, Yogyakarta" Ners dan Kebidanan Indonesia. Diakses pada tanggal 9 Desember 2016.
Wardani, M.S. 2012. Faktor Faktor yang Mempengaruhi Status Gizi Balita di RW 06 Kelurahan Pancoran Mas Kecamatan Pancoran Mas Depok. Skripsi. FKUI, Jakarta.

${ }^{1}$ Dosen Akper Panti Kosala

Surakarta

${ }^{2}$ Mahasiswa Akper Panti Kosala Surakarta 